\title{
Macroeconomic Uncertainty in South East Asia: A Comparative Study between Malaysia and Indonesia
}

\author{
Yee Peng Chow ${ }^{1, *}$, Junaina Muhammad ${ }^{2}$, Bany Ariffin Amin Noordin ${ }^{2} \&$ Fan Fah Cheng ${ }^{2}$ \\ ${ }^{1}$ Putra Business School, Universiti Putra Malaysia, 43400, Serdang, Malaysia \\ ${ }^{2}$ Faculty of Economics and Management, Universiti Putra Malaysia, 43400, Serdang, Malaysia \\ *Correspondence: Putra Business School, Universiti Putra Malaysia, 43400, Serdang, \\ Malaysia. E-mail: chowyeepeng@gmail.com
}

Received: May 7, 2017 Accepted: July 12, 2017 Published: November 16, 2017

doi: 10.5296/rae.v9i4.11187 URL: https://doi.org/10.5296/rae.v9i4.11187

\begin{abstract}
This paper examines the historical pattern of macroeconomic uncertainty of two developing countries in the South East Asia, namely Malaysia and Indonesia. Comparisons of macroeconomic uncertainty are also made between both countries using a selected number of indicators for macroeconomic volatility. We find that while both countries were affected by similar external sources of macroeconomic uncertainty, these countries were also subject to domestic sources of macroeconomic uncertainty which were confined to the particular country. The analyses also reveal that Indonesia experienced more fluctuations compared to Malaysia when macroeconomic uncertainty is measured by volatility as a macroeconomic outcome and domestic sources of macroeconomic volatility. Contrarily, Malaysia displayed greater fluctuations than Indonesia when macroeconomic uncertainty is measured by external sources of macroeconomic volatility. Policy implications are drawn from the findings.
\end{abstract}

Keywords: Macroeconomic uncertainty; Macroeconomic volatility; South East Asia; Malaysia; Indonesia 


\section{Introduction}

According to Katz and Bernat (2010, p. 2), "the interaction between macroeconomic turbulence, structural change and microeconomic behavior appears as an interesting topic worth examining". Although the authors are referring to the volatile macroeconomic condition in Argentina and how various industries in the country responded to the uncertainties caused by the country's decision to abandon the currency board regime in the late 1990s, the authors have correctly highlighted an important issue influencing microeconomic behavior of firms and other institutions, i.e. macroeconomic turbulence or uncertainty.

Macroeconomic uncertainty normally arises during times of crises or recessions. For instance, one of the most devastating crises was the Asian financial crisis (AFC) of 1997. This crisis, which started from Thailand and later spread to other countries such as Malaysia, Indonesia and Korea, had severely affected the capital markets of the region, where within a one-year period, the stock market values declined by more than $30 \%$. Huge outflows of foreign investments from the capital markets of these countries also took place, where in 1996, the amount of capital that flowed into the five countries most severely affected by the crisis (i.e. Malaysia, Thailand, Indonesia, the Philippines and Korea) was USD93 billion but in 1998, USD105 billion flowed out of these countries. The amount of capital outflows, which primarily consists of portfolio and banking flows, from these five countries was approximately $10 \%$ of the sum of their Gross Domestic Product (GDP) before the crisis (Wagner, 2003).

About a decade later, countries across the world were hit by another financial crisis. The Global Financial Crisis (GFC) of 2008, which originated from problems in the financial systems of developed countries, rapidly spread to various countries around the globe during the last quarter of 2008 and first half of 2009. This subsequently caused disruption in the asset markets and stunted the short-term growth prospects of these countries. The crisis had clearly demonstrated how closely linked are the financial markets around the world, and how shocks in one part of the global financial system can affect other parts of the system as well. The crisis also showed the dangers of deeper trade and financial linkages, which can serve as a mechanism for magnifying shocks and intensifying their effects on the country's economy (Kose and Prasad, 2010).

The GFC had created renewed pressure on volatility to economies across the world. This fact is also supported by Cucculelli and Bettinelli (2016) who claim that the economic environment has became significantly more unstable and turbulent in the last decade. Emerging market economies and developing economies are particularly vulnerable due to their higher openness to trade and less developed financial markets. These countries have charted remarkable trade expansion through domestic liberalization under the auspices of the General Agreement on Tariffs and Trade and World Trade Organization. While the process has contributed to the economic growth of these countries, at the same time, it has made these countries more vulnerable to external shocks (Olaberria and Rigolini, 2009).

Although macroeconomic uncertainty largely arises during times of crises, uncertainty can 
also arise on other occasions, particularly during "bad news" events. For instance, during times of volatile global commodity and energy prices, fiscal uncertainties, exchange rate volatility, political unrests and geopolitical tensions. Furthermore, there is evidence indicating that although the GFC had ended, some economies continued to experience volatility. For instance, Goldman Sachs Investment Strategy Group (2013) reports that the realized volatility in emerging market assets doubled in 2013 while the rolling three-month volatility in equities more than doubled from a trough of $8 \%$ to $19 \%$ within the same year. Meanwhile, local debt volatility tripled from a trough of $4 \%$ to $13 \%$, and the realized volatility and implied volatility of emerging market currencies tripled and nearly doubled, respectively. According to the International Monetary Fund (IMF) (2015), this observed volatility could be attributed to cyclical factors such as the U.S. Federal Reserve tapering and a slowdown in China's economy.

Taken together, the uncertain macroeconomic conditions experienced by countries across the world, sometimes at a rather dramatic level, may have destabilizing effects on the aggregate income, social welfare and business operations of these economies. This situation is even more severe among emerging market economies and developing economies. Hence, the understanding of the sources of macroeconomic uncertainty may assist policy makers, firms and other institutions to formulate appropriate policies or strategies to deal with such adverse situations. This paper primarily focuses on macroeconomic uncertainty in the South East Asia, where two developing countries namely Malaysia and Indonesia are chosen as case studies. Since independence, the Malaysian and Indonesian economy had experienced multiple episodes of macroeconomic instability. The question arises as to what are the major sources of macroeconomic uncertainty faced by each country, and how do these sources of macroeconomic uncertainty fluctuate over time.

The main thrust of this paper is to analyze the historical pattern of macroeconomic uncertainty of Malaysia and Indonesia since the countries achieved independence until 2014. The paper also aims to compare the macroeconomic uncertainty faced by both countries using a selected number of indicators for macroeconomic volatility for the period 2004-2014. In order to conduct our analyses, this study relies on published data from various reliable databases.

This paper is organized as follows. Section 2 and Section 3 provide analyses on the historical pattern of macroeconomic uncertainty for Malaysia and Indonesia, respectively. This is followed by comparisons of macroeconomic uncertainty between both countries using a selected number of indicators for macroeconomic volatility in Section 4. Lastly, Section 5 concludes the paper.

\section{Malaysia}

\subsection{Malaysia: 1957-1996}

Since achieving its independence in 1957, Malaysia, a middle-income country, has undergone several phases of economic transformation with the primary aims to develop and modernize 
the country and to alleviate poverty amongst the population. From 1971 through late 1990s, Malaysia has transformed itself from an agricultural trade oriented economy into an emerging multi-sector economy.

Malaysia's annual real GDP growth had increased steadily from an average of $4.1 \%$ in the 1950 s to $8.3 \%$ in the 1970 s (Zain, 2003). However, the rate of economic growth had considerably slowed down during various episodes of recessions and structural problems encountered by the country. Overall, Malaysia had undergone five major economic crises since its independence in 1957, where the first two crises were the oil crises of 1973-1974 and 1980-1981, the third crisis was the commodity crisis of 1985-1986, the fourth crisis was the currency or financial crisis of 1997-1998, and the latest crisis was the GFC of 2008-2009.

For instance, in 1985, Malaysia being a small open economy with exports at $49.1 \%$ of GDP, with primary concentration in commodities (which accounted for $66.7 \%$ of total exports), was particularly vulnerable to fluctuations in commodity prices and world output. During this period, investments in the country were dominated by the public sector, which accounted for $30.9 \%$ of total domestic demand. The Malaysian economy was vulnerable mainly due to the counter-cyclical policies adopted by the Malaysian authorities to mitigate the effects of the prevailing global recession (where there was a global decline in the prices of major commodities), as well as the Government's involvement in the heavy industries. According to the Central Bank of Malaysia or Bank Negara Malaysia (BNM), although growth momentum was sustained as a result of these counter-cyclical policies, such policies had produced adverse effects such as twin deficits in the fiscal and external payment positions, as well as exacerbating the country's external debt position (BNM, 1998).

As a result of the 1985 recession, Malaysia's real GDP fell by $1.2 \%$ in that particular year, and prices in the property market declined by $10-30 \%$. At the same time, an increasing number of corporate bankruptcies were reported, and the health of the financial system was adversely affected mainly due to the failure of some deposit-taking cooperatives and illegal deposit-takers. Non-performing loans (NPLs) stood at approximately 30\% in 1988, and four commercial banks and eight finance companies were rehabilitated in 1989 (BNM, 1998).

In terms of the historical pattern of inflation in Malaysia, the country has experienced wide fluctuations in the inflation rate as measured by the percentage increase in the overall price level or Consumer Price Index (CPI). From 1957 to 1970, the average inflation ranged from $0.1-1.1 \%$. However, inflation rate spiked to $10.5 \%$ in 1973 and $17.4 \%$ in 1974 following the 1973-1974 global oil crisis. Another spike in the inflation rate happened in 1981, again due to another oil crisis, where the inflation rate stood at $9.7 \%$. Subsequent to this crisis, inflation rates moderated once again and averaged at 3.3\% throughout the 1980s (Zain, 2003). Prior to the AFC, Malaysia witnessed another round of hike in inflation rate during the period 1991-1994, which was mainly attributed to supply constraints.

In terms of the historical pattern of exchange rates in Malaysia, the ringgit has recorded significant volatility since it was allowed to float in June 1973 after the abolishment of the Bretton Woods system. The volatility of ringgit was further exacerbated by the commodity price shocks, economic recession and currency speculation. For instance, the heightened 
volatility experienced by the ringgit in the mid-1980s was chiefly attributed to the sharp decline in the terms of trade that triggered the recession, as well as speculative activity on the ringgit. Furthermore, Malaysia encountered another period of exchange rate volatility during the period 1992-1994 due to substantial capital inflows into the country (BNM, 1997).

In terms of the historical behavior of interest rates in Malaysia, particularly the movements of deposit rates, BNM (1997) reports that these rates were changed infrequently and recorded relatively low volatility during the 1970s. This was because during this period, deposit rates of the commercial banks were administratively set via consultations between BNM and the commercial banks. In 1978, deposit rates were liberalized and commercial banks were allowed to set their own deposit rates. This change in interest rate policy had contributed to relatively volatile interest rates during most of the 1980s, as commercial banks adjusted their deposit rates in response to changing liquidity conditions in the banking system. During the period 1986-1987, BNM introduced the pegged interest rate system and this change in interest rate policy had provided temporary relief to the volatility of interest rates. However, when the pegged interest rate system was abolished in 1987, volatility in interest rates increased once again and persisted into the 1990s, albeit at a lower level compared to that in the 1980 s.

At the same time, Malaysia has been maintaining a relatively open capital account, supported by liberal exchange controls. BNM (2009) reports that Malaysia has attracted foreign direct investment (FDI) for more than a century, which has been a primary contributor to the economic development of the country. As the Malaysian economy attains higher level of development, the nature of its capital flows has evolved accordingly. These developments can be divided into two distinct categories. First, the Malaysian financial system has become more accustomed to short-term capital flows, and this trend is in tandem with the global surge in this type of capital flows. In particular, portfolio flows have increased in both volume and volatility, posing potentially destabilizing effects on the country's exchange rates, financial markets and real economy. Second, an increasing number of Malaysian companies are investing abroad recently in search of new markets and growth opportunities.

BNM (1997) reports that prior to July 1997, there were already signs of imbalances in the Malaysian economy, particularly in terms of its current account deficit, high credit growth and asset inflation. For instance, Malaysia's strong economic performance had attracted substantial short-term capital funds inflow in 1993, which had caused an overheating of the economy. Majority of the short-term funds was invested in the Malaysian stock exchange, previously known as Kuala Lumpur Stock Exchange (KLSE) (Note 1), causing its market capitalization to grow to $375 \%$ of GDP at the end of 1993. In fact, share prices and market turnover reached their phenomenal record highs by September 1993. On January 5, 1994, the Kuala Lumpur Composite Index (KLCI) hit 1,314 points before undergoing a sharp correction. During the period of rising KLCI, stock market speculation and asset price inflation began to emerge and caused price inflation to scale greater heights. Besides that, the shift in the relative importance of the public sector to the private sector as the primary engine of growth also generated new risks. According to BNM (1998), loans to the private sector rose to $148.4 \%$ of GDP in 1998 compared to $98.5 \%$ in 1990 due to the sluggish bond market 
development. These loans were backed by collaterals in the form of shares and properties which caused the banking system to be susceptible to falling asset prices.

\subsection{Malaysia: 1997-2007}

The AFC was triggered by the decision of the Thai monetary authorities to float the Thai baht in July 1997. The devaluation of the baht had resulted in strong pressures to build up against the Malaysian ringgit. The ringgit came under attack as speculators or currency traders began placing bets on the depreciation of the ringgit in July 1997. Due to heavy speculation on the Malaysian ringgit and panic selling activities in the mid-1997, the Kuala Lumpur foreign exchange market experienced a record high annual volume of RM1,318.2 billion. The transaction size under normal condition ranged from USD3-5 million but during the AFC, the size of each transaction ballooned to staggering amounts of USD50-100 million. In fact, there were even orders amounting to USD200-500 million (Zain, 2003).

The country's economic situation experienced dramatic changes since July 1997, and continued to worsen as the AFC became more intense and widespread. Among the outcomes of the crisis were the successive weakening of the ringgit, escalating inflation, huge losses in the equity market and large outflows of non-resident short-term capital. For instance, BNM (1997) reports that by the end of 1997, the ringgit lost about $35.1 \%$ of its value against the U.S. dollar. As a consequence of the weakening ringgit, the inflation rate charted a significant increase in early 1998, where the CPI rose at an average rate of $3.9 \%$ during the first two months of 1998. In fact, the inflation rate peaked at $6.2 \%$ in June 1998 but moderated thereafter. Meanwhile, the Producer Price Index (PPI) jumped sharply in the fourth quarter of 1997 to $7.2 \%$, from $2.8 \%$ in the first quarter of the year. Besides that, the Malaysian stock market lost about $44.8 \%$ from the end-June position. The crisis also badly affected the banking sector in Malaysia given the high dependency of Malaysian companies on bank loans. Due to the higher interest rates, some of the borrowers' creditworthiness was adversely affected. For instance, as a result of sharp depreciation in the values of their assets, the corporate sector suffered from significant loss of wealth. Some corporations also encountered difficulties in servicing their debts as corporate cash flows and incomes deteriorated. This situation had led to a significant increase in the number of loans which had turned to NPLs. For instance, the total NPLs of Malaysian commercial banks rose from RM4.3 billion in 1996 to RM22.7 billion in 1998. Lending activities by the banking sector subsequently slowed down (Zain, 2003).

Initially, BNM attempted to stabilize the ringgit by intervening in the foreign exchange market. This had led to tighter liquidity and significantly higher interest rates. For instance, BNM (1997) reports that the overnight and three-month interbank rates recorded a significant jump to $40 \%$ and $8.6 \%$, respectively, on July 10,1997 from $7.5 \%$ and $7.9 \%$, respectively, the day before. However, BNM realized that the uncertainty in the foreign exchange market would be prolonged after the Philippines floated its peso on July 11, 1997. Subsequently, BNM resorted to lowering the interest rates in order to restore the stability in the domestic financial market and to mitigate the effects of external developments on the country's real sector. In addition, BNM also introduced measures to curb speculation on the ringgit, where 
with effect from August 4, 1997, a USD 2 million limit was imposed on outstanding non-commercial related ringgit offer-side swap transactions between the banking institutions with each foreign customer. Despite government's intervention, BNM (1998) reports that the ringgit subsequently fell to a historic low of RM4.88 against the U.S. dollar on January 7, 1998.

The Malaysian authorities have introduced various other measures in response to the crisis. For instance, the Government agreed to guarantee deposits placed with the banking institutions in late 1997. In January 1998, BNM announced the plan to merge the finance companies in order to consolidate and strengthen the industry. This was followed by the establishment of Pengurusan Danaharta Nasional Berhad (Danaharta) in June 1998, and Danamodal Nasional Berhad (Danamodal) and the Corporate Debt Restructuring Committee (CDRC) in August 1998. Danaharta's main role was to acquire and manage the NPLs of financial institutions in order to maximize their recovery value, while Danamodal was involved in the recapitalization of the weak financial institutions in which funds were injected to facilitate the smooth running of their operations. Meanwhile, the primary function of CDRC was to assist both creditors and debtors in finding out-of-court solutions to their debt problems so that corporations could continue with their normal operations.

In July 1998, the National Economic Action Council also announced a comprehensive National Economic Recovery Plan to restore stability and expedite economic recovery. Subsequently, on September 1, 1998, the Malaysian authorities imposed selective exchange controls to prevent the internationalization of the ringgit and to stabilize short-term capital flows. On September 2, 1998, the ringgit was pegged at RM3.80 against the U.S. dollar. This was followed by further relaxation of the country's monetary policy in an attempt to improve liquidity conditions and lower the cost of funds. Overall, Malaysia's real GDP deteriorated by $7.5 \%$ in 1998 after charting 12 years of uninterrupted expansion at an average rate of $7.8 \%$ per annum (BNM, 1999).

Although Malaysia has recorded significant economic recovery since 1999, uncertainties in the economic and business environment still prevailed in the early 2000s, especially due to concerns over the impact of the slowdown in the U.S. economy and the global electronics downturn on the Malaysian economy. Growth prospects were further dampened in 2003 by the outbreak of the Severe Acute Respiratory Syndrome (SARS), particularly its impact on the country's tourism, transport and retail services, as well tensions in the Middle East. In 2004, there were notable shocks to the global economy due to increasing inflationary pressures, high oil prices, tightening of the global monetary cycle, the occurrence of tsunami as well as sporadic outbreaks of avian flu.

As a move to further deregulate and liberalize the domestic environment, the Malaysian authorities introduced a major policy initiative on July 21, 2005, i.e. shifting the exchange rate regime from a pegged exchange rate against the U.S. dollar to a managed float. Under this new regime, BNM no longer targets a certain level of exchange rate. Instead, it only intervenes to smooth out volatility in the exchange rates, particularly when excessive movements in the exchange rate occur due to large short-term capital flows. BNM (2005) 
reports that the ringgit subsequently appreciated to 3.7460 against the U.S. dollar before closing the year at 3.78 .

Prior to the GFC, Malaysia continued to face challenges from uncertainties arising from escalating global prices of primary and food commodities as well as instability of the global financial markets, particularly related to the deterioration in the U.S. subprime mortgage market in 2007.

\subsection{Malaysia: 2008-2014}

The external developments in the global markets in 2008, particularly the rising prices of primary and food commodities, had created intense inflationary pressure in Malaysia. According to BNM (2008), inflation peaked at 8.5\% in July 2008, while for the year 2008 as a whole, inflation averaged at $5.4 \%$. The impact of the escalating global prices of commodities was even more obvious in the PPI, which peaked at $14.4 \%$ in June 2008 . Meanwhile, the commodity component of the PPI hit 42.5\% in June 2008 before charting a rapid decline to $-10.4 \%$ by the end of 2008 .

Due to the GFC, the Malaysian economy started to slow down in late 2008. According to World Bank (2009), growth declined from $6.3 \%$ in 2007 to $4.6 \%$ in 2008 , and this decline was chiefly driven by a drop in private capital formation and external demand. The crisis led to a contraction in Malaysia's export performance. BNM (2009) reports that Malaysia's gross exports further deteriorated by $20 \%$ during the first quarter of 2009 after recording a negative growth of $7.4 \%$ in the final quarter of 2008 .

Although Malaysia's economic growth showed positive recovery in 2010, being a highly open economy, the country continued to be vulnerable to the spillover effects of various global developments. For instance, in 2010, Malaysia was exposed once more to the threat of escalating global commodity and energy prices as well as quantitative easing measures by the advanced economies. Meanwhile, in 2011, macroeconomic uncertainty was heightened following the escalation of the European debt crisis, fiscal uncertainties in the U.S and increased capital flow volatility. Subsequently, in 2014, the country was confronted with adverse external developments such as uncertainty regarding the monetary policy normalization in the U.S., the sharp decline in crude oil and other commodity prices, and unfavorable developments in the euro area.

\section{Indonesia}

\subsection{Indonesia: 1945-1996}

Since its independence in 1945, Indonesia has undergone a series of changes in its economic policies. When Indonesia first came under the administration of President Sukarno (also known as the Old Order administration) until 1965, the Government pursued a nationalistic, quasi-socialist economic policy. During his regime, the Indonesian economy was very much dependent on fiscal stimulus financed by money creation. This policy mix had resulted in accelerated inflation, economic stagnation and a collapse in confidence (Amerasinghe and 
Modesto, 2011). During Sukarno administration, the dominant sector in the economy was agriculture, followed by trade and manufacturing (Bayhaqi, 2006).

Subsequently, President Suharto took over the country's administration (also known as the New Order administration) and his regime lasted until the AFC in 1998. Suharto adopted more market-oriented economic policies, where upon assuming power, his Government quickly introduced a macroeconomic stabilization program and the country's trade and investment policies were subsequently liberalized. For instance, the Government introduced the first regulation on FDI, i.e. the Foreign Investment Law No. 1/1967 in 1967, where foreign investors were offered substantial incentives such as guarantees and tax exemptions (Amerasinghe and Modesto, 2011). Similar to the Sukarno administration, agriculture remained the dominant sector in the economy during the period 1966-1970 (Bayhaqi, 2006).

In the wake of the commodity boom of 1972-1973 and the oil price crisis of 1973-1974, the Government shifted from an open door policy and adopted an increasingly inward-looking trade policy, where the import substitution strategy was pursued. However, in the mid-1980s, the Government reverted to a more market-oriented economic policy once again, where private sector investment became the main driver of economic growth. This change in policy stimulated FDI inflow and contributed to restoring the country's economic growth (Amerasinghe and Modesto, 2011). The period 1971-1981 also marked a structural change in the Indonesian economy, where industrialization began to take over agriculture as the dominant sector in the economy. However, these industries were very dependent on imports, where most of the raw materials and capital goods were still imported (Bayhaqi, 2006).

Beginning from 1982, the Government started to shift toward export-oriented industrialization strategy and deregulated its industries. This policy change had triggered excessive borrowing from offshore among the financial institutions, private conglomerates and state-owned enterprises to invest in mega-projects producing goods for the highly protected local market. These mega projects were estimated to involve USD70 million in foreign loans at the height of the debt blowout in 1991. This had created pressures on inflation and the rupiah, and the Indonesian economy was showing signs of overheating. The Government responded by attempting to scale down domestic economic activities via reduction of domestic money supply, ensuring the banking system was equipped with systems for prudential control and cutting the overseas loans for mega projects. For instance, a drastic cut on the liquidity of state banks took place in 1987 and 1991, and in total 10 trillion rupiah worth of liquidity was removed from the system. These actions triggered interest rates to soar to above 30\% and the economy to slow down (Bayhaqi, 2006).

Overall, the country registered high growth rate averaging 7\% for the period 1967-1997 (immediately before to the AFC). However, the country's economic growth was slowed down by several episodes of macroeconomic imbalances. For instance, the country faced an economic crisis in 1966, and this prompted the Indonesian government to open up the economy to foreign investment as a way to resolve the crisis (Bayhaqi, 2006). The government policies were also substantially affected in 1986 by the collapse of the oil sector.

In terms of the historical pattern of foreign exchange in Indonesia, although the Suharto 
administration adopted a pegged exchange rate regime, the authorities tried to keep the Indonesian rupiah close to its market value via a series of devaluation in the 1970s and 1980s to enhance the competitiveness of its export commodities. During the 1990s, the nominal exchange rate continued to depreciate relative to the U.S. dollar as a result of the deliberate policy by the Indonesian authorities which targeted an annual depreciation of between $4 \%$ and $5 \%$. However, due to escalating prices, the real exchange rate started to appreciate, especially after 1994, signaling the country's loss of international competitiveness (Harvie, 1999).

In terms of the historical behavior of inflation in Indonesia, the country experienced several episodes of high inflation periods. For instance, during the Sukarno administration, the high dependence on fiscal stimulus financed by money creation had resulted in extremely high inflation levels. In 1965, the country's inflation peaked at 1,500\% (Amerasinghe and Modesto, 2011). Meanwhile, during Suharto's presidency, one of the primary economic policy objectives was to stabilize the economy by containing inflation, and the Government managed to do so using orthodox monetary and fiscal policies. However, the oil price shocks of 1973-1978 and 1979-1981 had created inflationary pressures. In 1991, the debt blowout from excessive borrowing activities among the financial institutions, private conglomerates and state-owned enterprises to invest in mega-projects had also created inflationary pressures (Bayhaqi, 2006). Since 1993, the Government's tight monetary policy managed to contain inflation to remain well below 10\%. For instance, the inflation averaged at $7.9 \%$ in 1996 compared to $9.4 \%$ in the previous year (Harvie, 1999).

Prior to the AFC, the Indonesian economy was already showing some signs of weakness. For instance, the country's current account balance had been deteriorating since 1993. This problem was exacerbated by the increasing reliance on short-term foreign capital flows to finance the deficit, which had contributed to the steady accumulation of short-term foreign debt in excess of foreign exchange reserves. In addition, the Indonesian economy also faced problems with a relatively weak banking system, oversupply in the property market and deteriorating export and import growth (Harvie, 1999).

\subsection{Indonesia: 1997-2007}

In 1997, Indonesia experienced the worst economic crisis since its independence. Sinnakkannu and Nassir (2008) report that rumors about the potential further weakening of the Indonesian rupiah caused the currency to depreciate by $2 \%$ on August 13, 1997. On the next day, the Central Bank of Indonesia or Bank Indonesia (BI) announced that it had decided not to intervene in the rupiah anymore and allowed the currency to float. This news came as a shock to the corporate community who thought that BI would never give up on defending the rupiah, and raised a major concern among the corporations since 45\% of Indonesia's USD120 billion debts were corporate and majority of these debts were not hedged against foreign exchange risk. Accordingly, the Indonesian rupiah against the U.S. dollar shot up to over 3,500 as corporations in Indonesia tried to hedge their debts at the last minute. The exchange rate further deteriorated to 3,870 on October 6, 1997 as rumors about potential corporate losses, rating downgrades, bond defaults and the collapse of the banking system spread. In 
January 1998, the Indonesian rupiah almost collapse. Overall, between June 1997 and December 1998, the Indonesian rupiah had fallen by 70\% against the U.S. dollar.

Overall, the crisis had severely affected the Indonesian economy, where the country suffered the largest output contraction of $13.1 \%$ in 1998. Meanwhile, inflation soared dramatically during 1998, recording an average of around $60 \%$ for the whole year, while inflation rate stood at slightly below $80 \%$ by the end of 1998 (Harvie, 1999). Gill and Kharas (2007) report that the crisis had resulted in a significant drop in FDI to Indonesia, where the country used to receive $25 \%$ of the Japanese FDI to emerging Asia in 1992, but merely 3\% in 2004. At the same time, BI (2008) reports that the Indonesian Composite Stock Index tumbled by $62 \%$ during the period June 1997 to September 1998. Besides having to deal with the aftermath of the crisis, the Indonesian economy also had to face intensifying challenges being brought about by the worst drought in the country's 50-year history, plummeting international oil prices and social unrest in the country (Harvie, 1999).

In response to the crisis, Indonesia sought assistance from the IMF on October 8, 1997. The IMF came out with a USD43 billion financial support package for Indonesia. As part of the measures to meet the conditions stipulated in the IMF package, 16 commercial banks were closed, non-essential infrastructure projects were postponed and the Indonesian Bank Restructuring Agency was established to consolidate and recapitalize weak financial institutions.

Following a series of bloody riots, President Suharto eventually resigned in May 1998, and B.J. Habibie assumed presidency until 1999. During President Habibie's short presidency, the country shifted to decentralization as the new national policy (Bayhaqi, 2006). In 2000, the Indonesian economy started to recover, posting growth of $4.8 \%$. However, the political situation in Indonesia became volatile following the Parliament's censure of President Wahid in March 2001. This had contributed to the depreciation of rupiah and downgrading of Indonesia's long-term foreign currency rating by credit rating agency, Standard \& Poor's. Subsequently, the rupiah strengthened again as the political situation in the country improved following the commencement of Megawati Sukarnoputri's presidency.

In 2003, the Indonesian economy faced some serious challenges arising from the impact of the 2002 Bali bombing tragedy, the Government's decision to exit the IMF program, the global economic slowdown, the country's large debt overhang problem and other structural problems. In 2004, although the country continued to expand, it faced uncertainties stemming from the possibility of the tightening of monetary policy by the U.S., China's actions to slow down its economic expansion, soaring world oil prices and rising political tensions prior to the legislative general election. These uncertainties coupled with other domestic structural weaknesses had triggered a reversal of short-term foreign capital flows, which had caused the rupiah to depreciate.

In 2005, the continued escalating international oil prices coupled with a hike in volatile food prices due to disruptions in the distribution networks in several regions caused the country's inflation to soar to $17.11 \%$, compared to $6.4 \%$ in 2004 . Both exports and imports also deteriorated significantly. For instance, export growth declined from $13.50 \%$ in 2004 to $8.6 \%$ 
in 2005 amidst the global economic slowdown and issues related to poor competitiveness. Meanwhile, import growth shrunk from $27.7 \%$ in 2004 to $12.35 \%$ in 2005 due to poor domestic demand. On top of that, the country had to deal with the aftermath of the tsunami disaster that hit the country at the end of 2004, and the efforts to rehabilitate the affected areas threatened the country's fiscal sustainability (BI, 2005).

Although the Indonesian economy improved in 2006, internal problems such as the delay in policy implementation of draft laws related to investment, taxation and labor, uncertainty over the provision of infrastructure in financed projects and implementation issues related to the Financial Sector Policy Package created uncertainties about business prospects in the country (BI, 2006). In 2007, the Indonesian economy was confronted with macroeconomic uncertainty arising from external developments such as escalating world commodity prices, particularly oil, and the unfolding of the subprime mortgage crisis. This had created downward pressures on the rupiah as foreign capital outflows escalated. According to BI (2007), the rupiah plunged to its lowest in August 2007 with a monthly average of 9,372 rupiah per U.S. dollar.

In terms of monetary policy after the AFC, BI gradually shifted its monetary policy from quantity targeting to price or interest rate targeting, and widened the exchange rate tolerance band. In August 1997, BI abandoned the crawling band exchange rate regime, and subsequently the rupiah was allowed to float. This had resulted in the sharp devaluation of the currency. After futile attempts to rescue the value of the rupiah by raising short-term interest rates and injecting large volume of liquidity into the banking system, BI eventually resorted to targeting the monetary base in its attempt to re-absorb the excess liquidity from the banking system. Subsequently in July 2005, the country formally shifted to inflation targeting following the enactment of a new central bank act in 1999 (Inoue et al., 2012). Overall, the Indonesian authorities followed a tight monetary stance post-AFC, where interest rates were kept at a relatively high level. However, as the economic condition in the country improved in 2006, BI progressively lowered the monetary policy rate (BI rate) where the rate was reduced seven times to $9.75 \%$, totaling 300 basis points, from May 2006 until the end of the year. In 2007, BI continued to revise the BI rate downwards (BI, 2006).

In terms of Indonesia's foreign economic policy, with the demise of the New Order regime following the AFC, Indonesia further liberalized its trade and investment policies, including the conditions imposed under IMF's structural adjustment program, such as the reduction of import tariffs and the removal of strict foreign ownership procedures. These changes augured well for FDI, where the level of FDI inflows into the country has grown from USD1,857 million during the period 1993-2003 to USD6,928.3 million and USD9,318.1 million in 2007 and 2008, respectively (Chandra, 2011).

\subsection{Indonesia: 2008-2014}

The Indonesian economy started to feel the full impact of the GFC in the last quarter of 2008. However, the impact of the crisis on Indonesia's economic growth was rather moderate, where the country only recorded a slight decline in real GDP growth from $6.3 \%$ in 2007 to $6.1 \%$ in 2008 . Nonetheless, the crisis had severely affected Indonesia's trade flows since late 
2008 and by January 2009, its export values recorded a year-on-year decline of $36.1 \%$, which was the largest monthly fall in a decade for the country. The sharp decline in export values was primarily driven by the dramatic drop in oil prices and associated deteriorations in other commodity prices. At the same time, as a result of falling commodity prices, Indonesia's inflation had slowed down accordingly where the 12-month inflation declined to $8.6 \%$ from its peak of over $12 \%$ in September 2008. Meanwhile, Indonesia's external position was also weakened by the crisis where although the country's current account recorded a small current account surplus of USD600 million, the portfolio outflows at the end of 2008 resulted in an overall deficit of USD1.9 billion, which was the first for the country since 2001 (World Bank, 2009).

Meanwhile, the rupiah depreciated and experienced greater volatility due to the crisis. For instance, the rupiah weakened by $5.4 \%$ from an annual average of 9,140 rupiah per U.S. dollar in 2007 to 9,666 rupiah per U.S. dollar in 2008. At the end of 2008, the rupiah was trading at 10,900 per U.S. dollar compared to the previous year-end closing rate of 9,393 rupiah per U.S. dollar, representing a $13.8 \%$ lost in value. The Indonesian stock market was also adversely affected by the crisis where the Indonesian Composite Stock Index losses reached 54\% for the period February to November 2008 (BI, 2008). According to Abdul Majid and Kassim (2009), the Indonesian stock market used to record positive average daily returns of $12.6 \%$ before the crisis (from February 15, 2006 to July 25, 2007) but during the crisis (from July 26, 2007 to December 31, 2008), it recorded average daily losses of $10.6 \%$.

Although the Indonesian economy started to recover in 2009, it still faced many uncertainties arising from factors such as the potential economic and financial risks triggered by the developed countries' exit strategy, internal structural issues and the potential for an asset bubble in the financial markets. In 2010, Indonesia faced increasing challenges in controlling the rising inflation triggered by anomalous weather conditions which caused disruptions in the supply of food staple, as well as escalating global commodity prices. According to BI (2010), the CPI inflation for 2010 stood at $6.96 \%$, while inflation of volatile food prices soared to $17.74 \%$ in 2010 , compared to merely $3.95 \%$ a year ago. In addition, Indonesia also experienced huge movements in capital flows and the value of rupiah due to the developments on the external front, particularly the Greek fiscal crisis. For instance, BI (2010) reports that capital inflows increased during the first quarter of 2010, but the negative market sentiment caused by the Greek crisis triggered a capital flight in the second quarter of the year. However, since a resolution to the Greek crisis was found in the second half of the year, Indonesia experienced yet another surge of capital inflows. Similarly, in the first half of 2011, immense capital inflows came into Indonesia, but a reversal happened thereafter as the European economic crisis worsened and the U.S. economy weakened.

In 2012, the Indonesian economy was affected by the economic slowdown of some of its trading partners, particularly China, and the contraction in global commodity prices. These developments had affected the country's exports performance, which in turn caused imbalances in the current account and value of rupiah. For instance, BI (2012) reports that export growth in 2012 was merely $1.1 \%$, a sharp contrast to the average historical level of $8.1 \%$ over the last ten years. Meanwhile, the current account reversed into a deficit of $2.7 \%$ 


\section{Al Macrothink}

of GDP, and the rupiah depreciated by $6.3 \%$. In 2013 and 2014, the Indonesian economy continued to moderate as it faced challenges arising from factors such as the global economic slowdown, the tapering off of the U.S. monetary stimulus, lower global commodity prices and escalating domestic food and fuel prices.

\section{Comparisons of Macroeconomic Uncertainty between Malaysia and Indonesia}

Next, this paper compares the macroeconomic uncertainty faced by both countries for the period 2004-2014 using three major categories of macroeconomic volatility indicators, namely volatility as a macroeconomic outcome, domestic sources of macroeconomic volatility and external sources of macroeconomic volatility.

\subsection{Volatility as a Macroeconomic Outcome}

Volatility as a macroeconomic outcome is represented by five indicators, i.e. growth rate of real GDP, growth rate of CPI, growth rate of PPI, growth rate of exports and growth rate of imports.

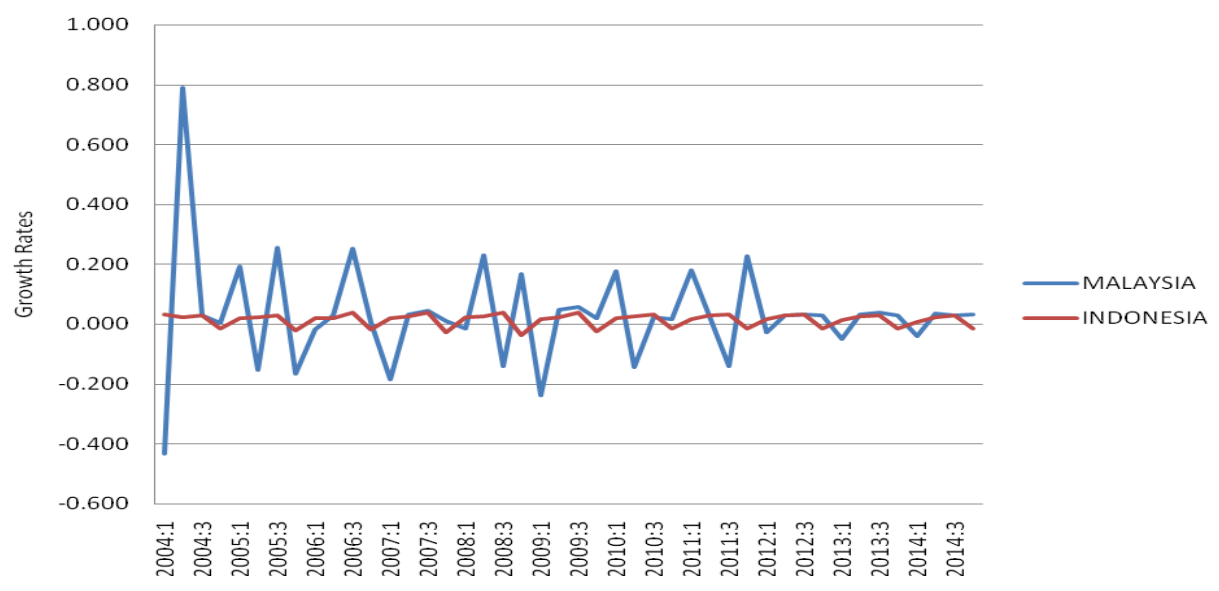

Figure 1. Growth Rate of Real GDP

Source: Authors' own calculations using data from IMF International Financial Statistics (IFS).

From Figure 1, it can be seen that the growth rate of real GDP of Malaysia exhibited much wider fluctuations compared to Indonesia over the study period. 


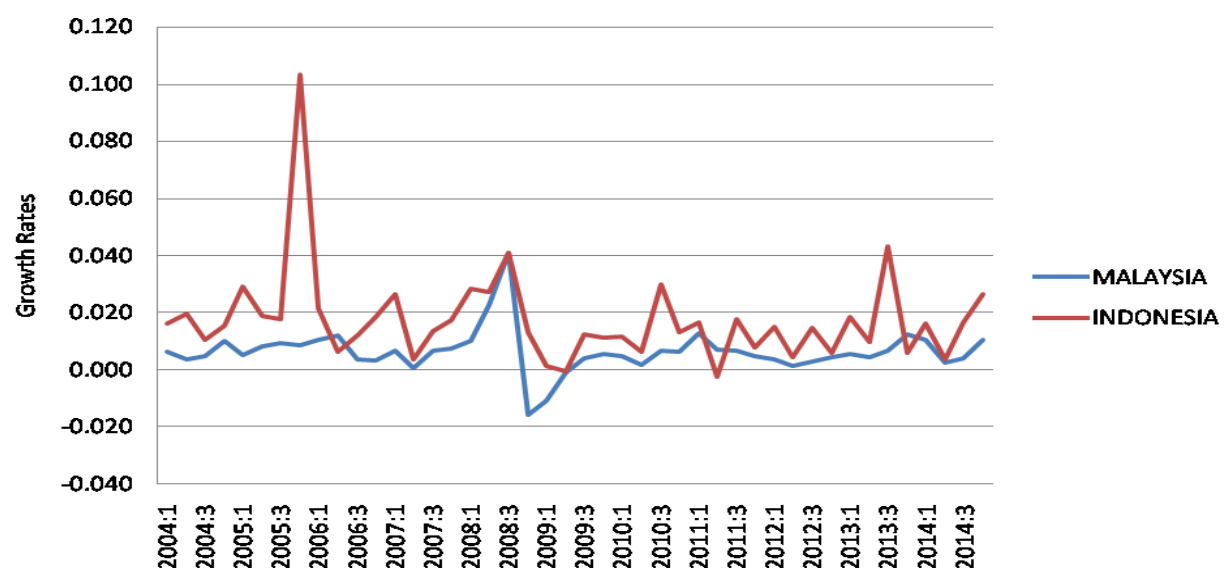

Figure 2. Growth Rate of CPI

Source: Authors' own calculations using data from IMF IFS.

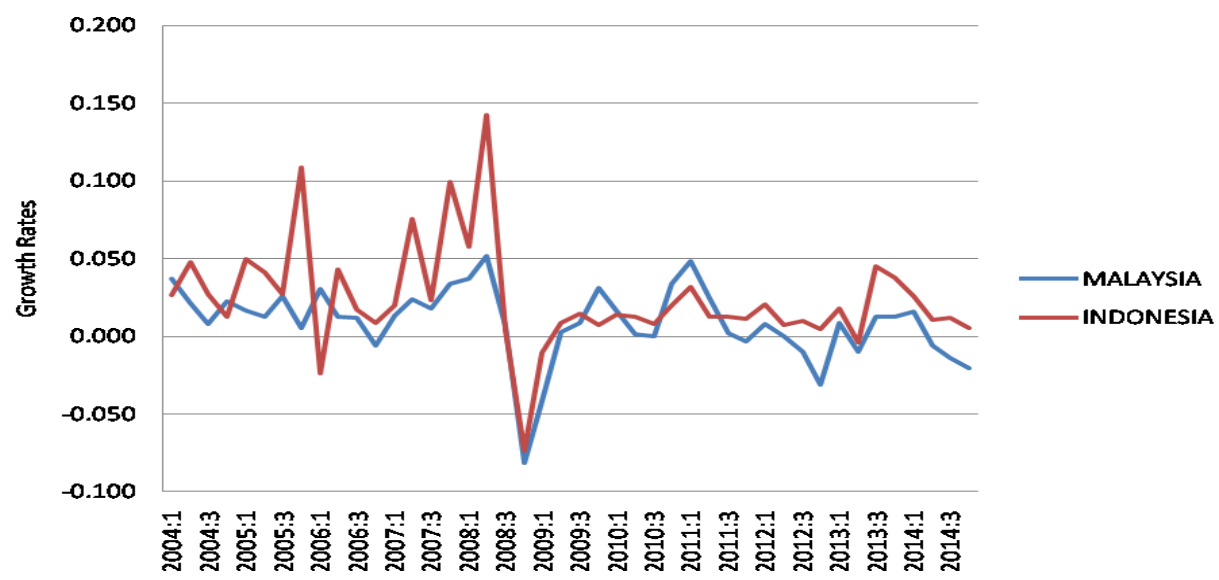

Figure 3. Growth Rate of PPI

Source: Authors' own calculations using data from IMF IFS.

Figures 2 and 3 depict the behavior of domestic prices. In general, the domestic prices for both countries tend to converge. In 2007, inflationary pressures as measured by both CPI and PPI began building up due to escalating global fuel and commodity prices but the trend was reversed in 2008 as the commodity prices experienced sharp correction, triggered by the deteriorating global and economic conditions during the GFC. In 2010, stronger signs of inflation began to emerge once again, given the escalating global commodity and food prices. Throughout this period, Indonesia generally recorded wider fluctuations in growth rates of CPI and PPI compared to Malaysia. 


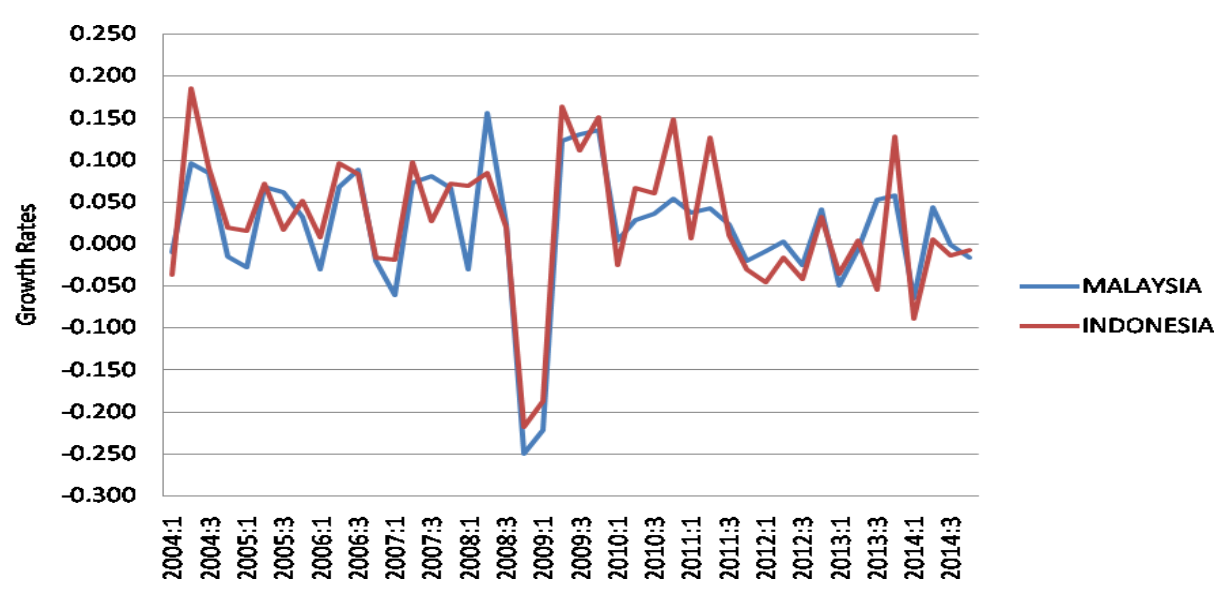

Figure 4. Growth Rate of Exports

Source: Authors' own calculations using data from IMF IFS.

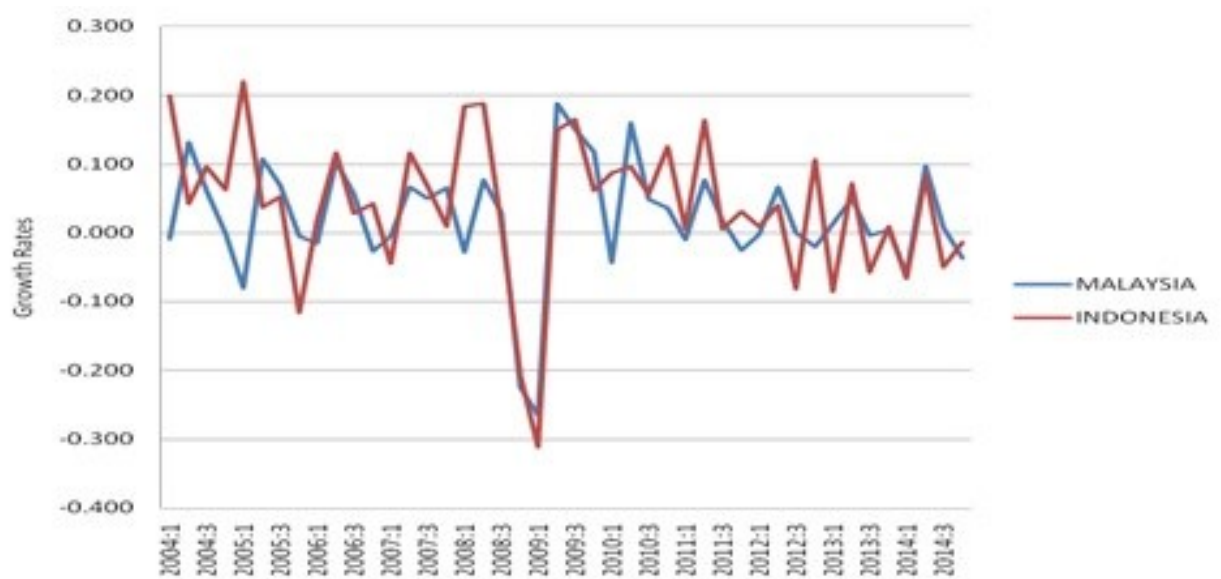

Figure 5. Growth Rate of Imports

Source: Authors' own calculations using data from IMF IFS.

Figures 4 and 5 show the growth rates of exports and imports, respectively. For most of the time, the growth rates of exports and imports for both countries tend to converge. Both growth rates also showed noticeable decline during the GFC.

\subsection{Domestic Sources of Macroeconomic Volatility}

Domestic sources of macroeconomic volatility is represented by six indicators, i.e. monetary growth, growth rate of nominal deposit rates, growth rate of nominal lending rates, fiscal result as a proportion of GDP, growth rate of real broad effective exchange rates and growth rate of openness coefficient. 


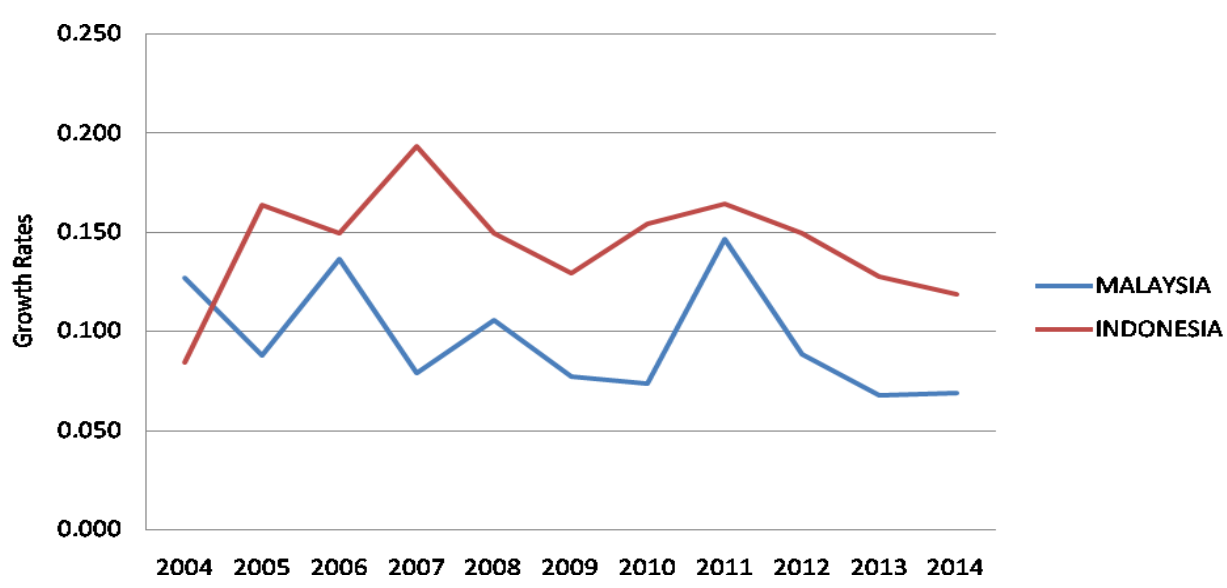

Figure 6. Monetary Growth (Growth Rate of Money and Quasi Money, M2)

Source: Authors' own calculations using data from World Bank World Development Indicators (WDI).

Figure 6 shows monetary growth over time. Monetary growth, as measured by the growth rate of money and quasi money (M2), had been positive for both countries, with Indonesia recording greater fluctuations compared to Malaysia over the study period.

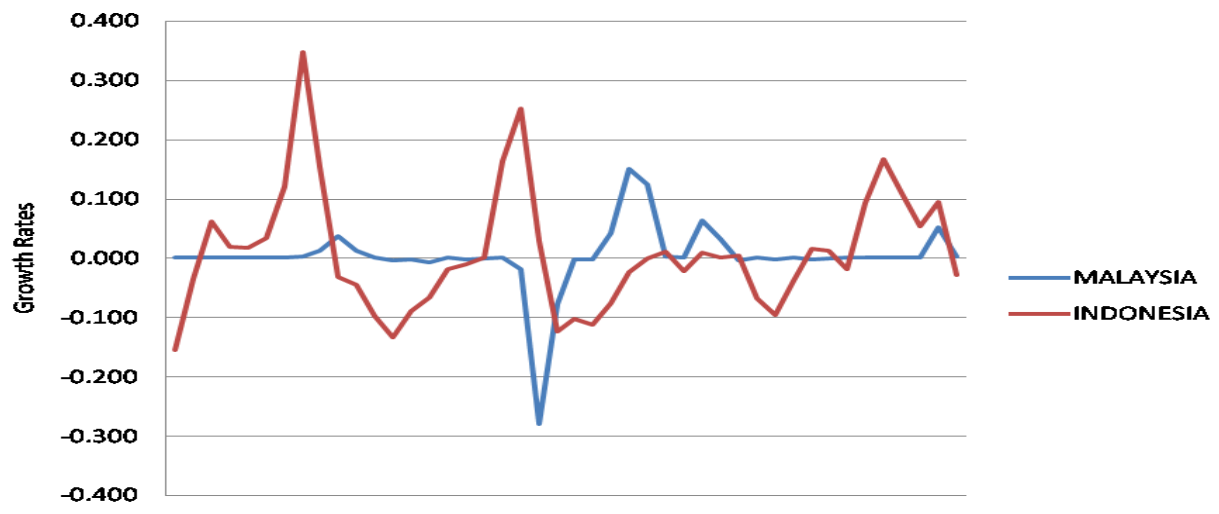

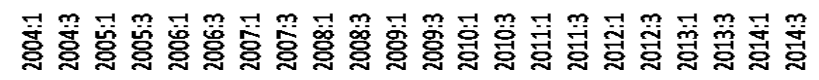

Figure 7. Growth Rate of Nominal Deposit Rates

Source: Authors' own calculations using data from IMF IFS. 


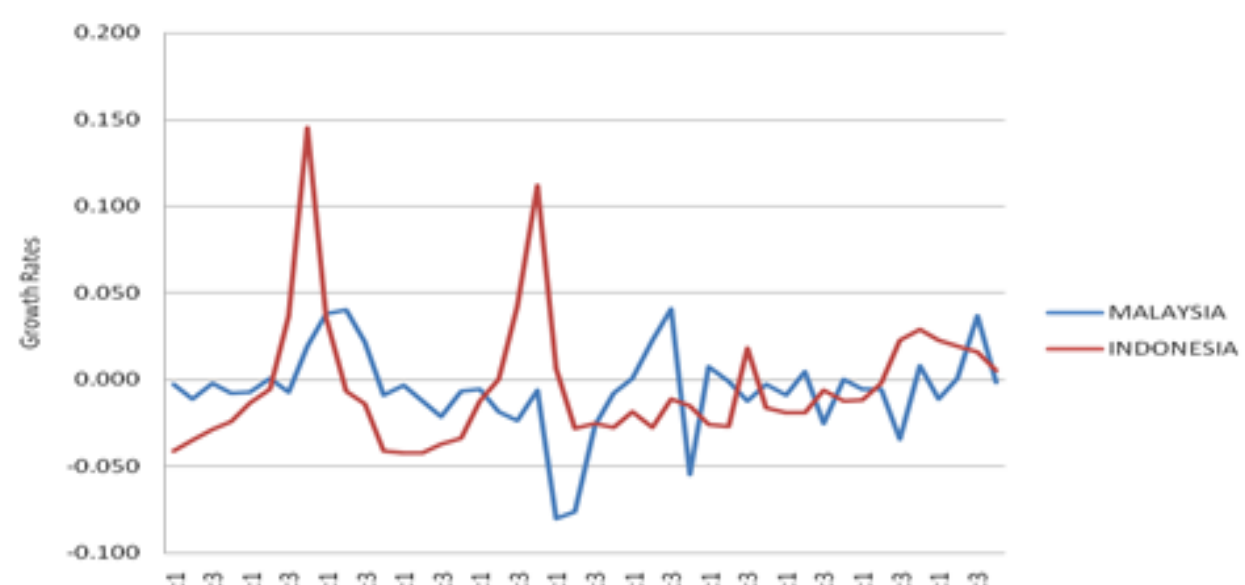

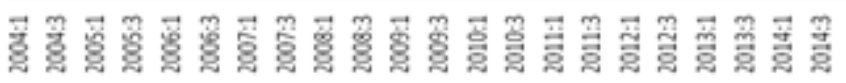

Figure 8. Growth Rate of Nominal Lending Rates

Source: Authors' own calculations using data from IMF IFS.

Figures 7 and 8 depict the behavior of domestic interest rates. In general, both the growth rates of nominal deposit rates and lending rates of Indonesia experienced wider fluctuations compared to Malaysia over the study period.

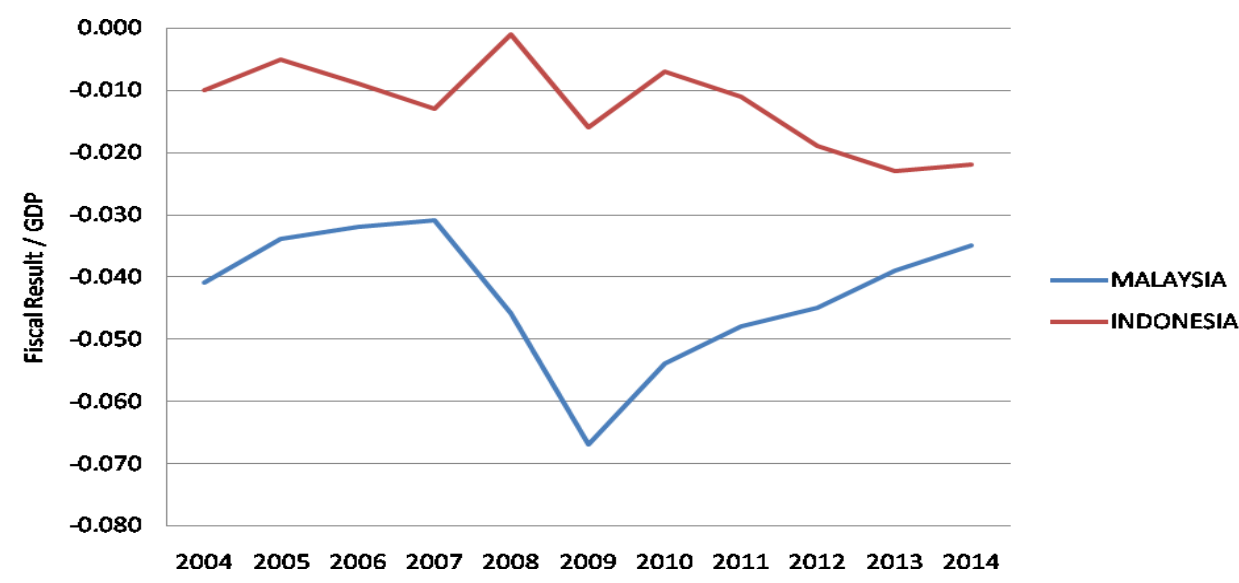

Figure 9. Fiscal Result as a Proportion of GDP

Sources: Authors' own calculations using data from United Nations Economic and Social Commission for Asia and the Pacific Statistical Database, Organization for Economic Co-operation and Development and central banks of various countries.

Figure 9 depicts the fiscal results over time. Both Malaysia and Indonesia pursued an expansionary fiscal policy and maintained a budget deficit. However, Malaysia recorded wider fluctuations in its fiscal results compared to Indonesia over the study period. 


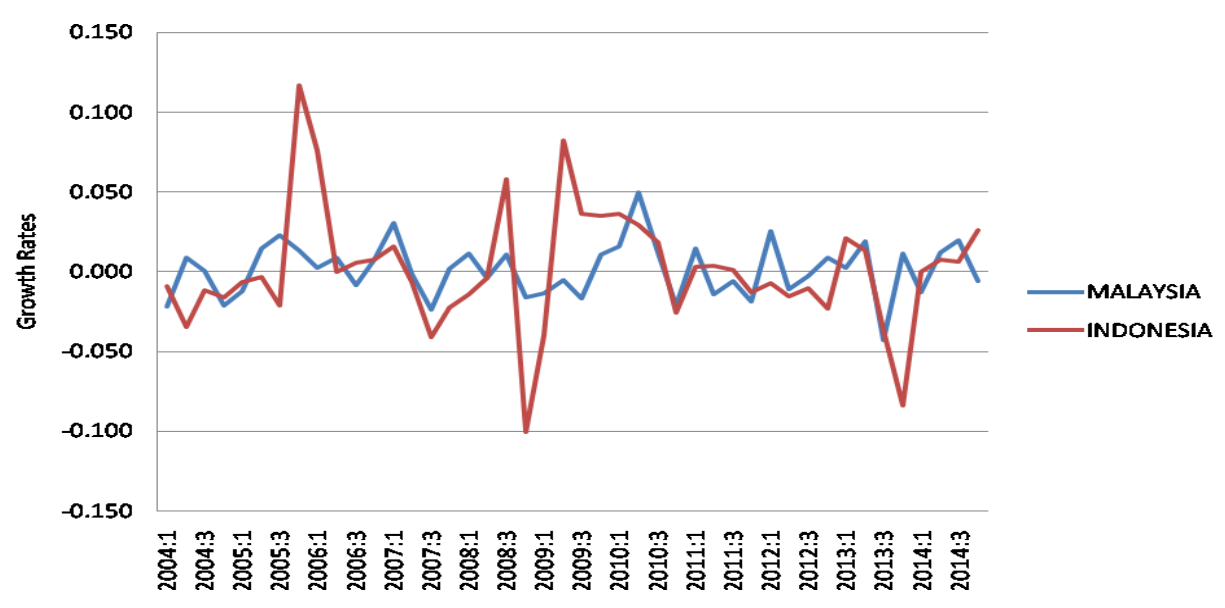

Figure 10. Growth Rate of Real Broad Effective Exchange Rates

Source: Authors' own calculations using data from Federal Reserve Economic Data (FRED).

Figure 10 depicts that the growth rate of real broad effective exchange rates had fluctuated more widely for Indonesia compared to Malaysia over the study period.

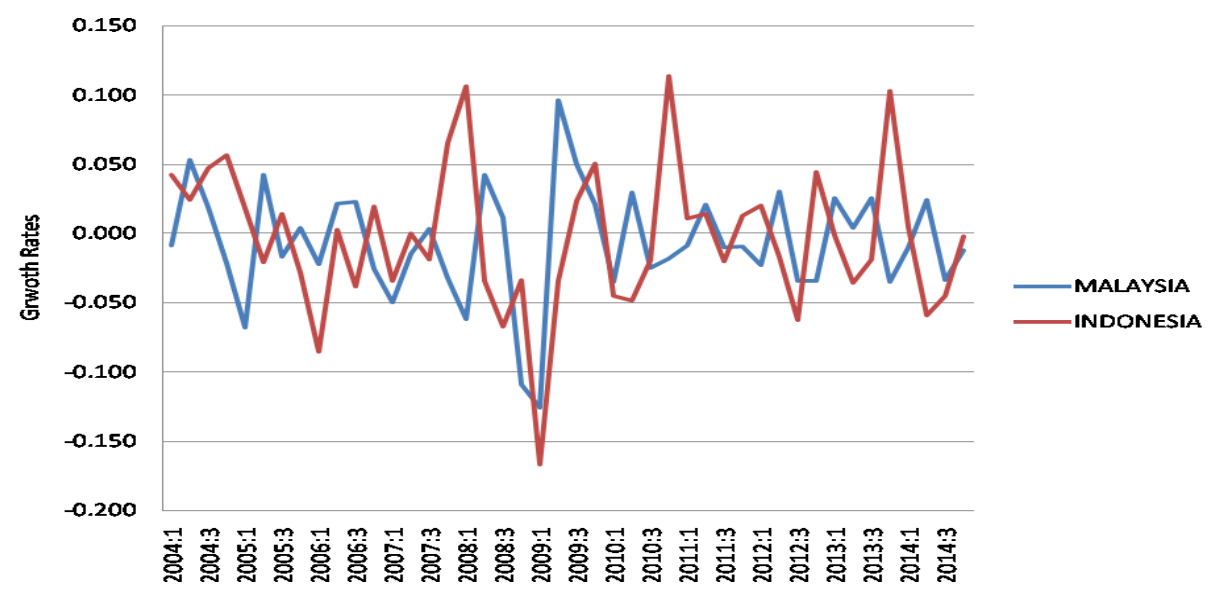

Figure 11. Growth Rate of Openness Coefficient (Note 2)

Sources: Authors' own calculations using data from IMF IFS and FRED.

Figure 11 depicts that the growth rate of openness coefficient had fluctuated more widely for Indonesia compared to Malaysia over the study period. Both countries experienced the sharpest decline during the GFC.

\subsection{External Sources of Macroeconomic Volatility}

External sources of macroeconomic volatility is represented by three indicators, i.e. growth rate of terms of trade, net FDI inflows as a proportion of GDP and net portfolio equity inflows as a proportion of GDP. 


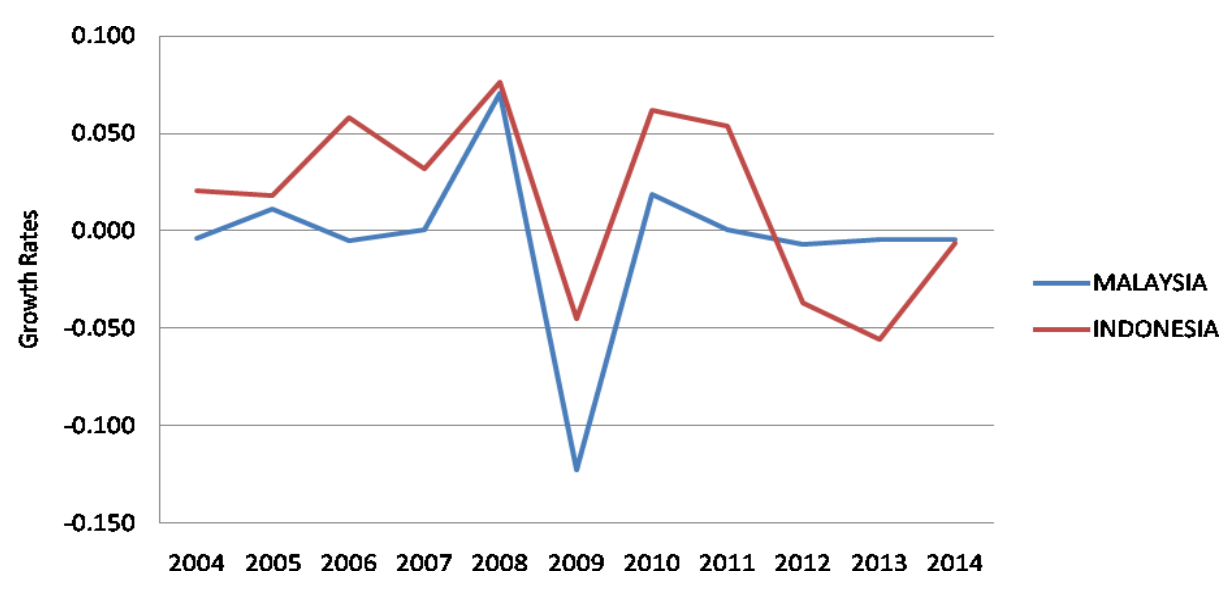

Figure 12. Growth Rate of Terms of Trade

Sources: Authors' own calculations using data from World Bank WDI and IMF IFS.

Figure 12 shows that the growth rate of terms of trade fluctuated more widely for Malaysia compared to Indonesia over the study period. Both countries experienced sharp decline during the GFC.

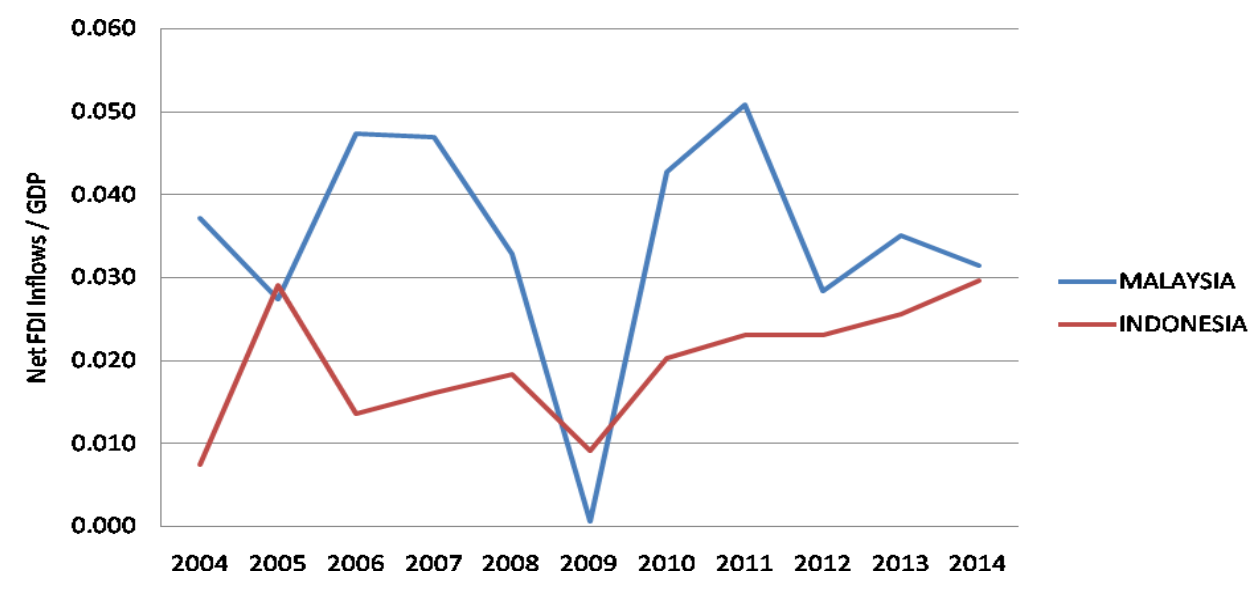

Figure 13. Net FDI Inflows as a Proportion of GDP

Source: Authors' own calculations using data from World Bank WDI. 


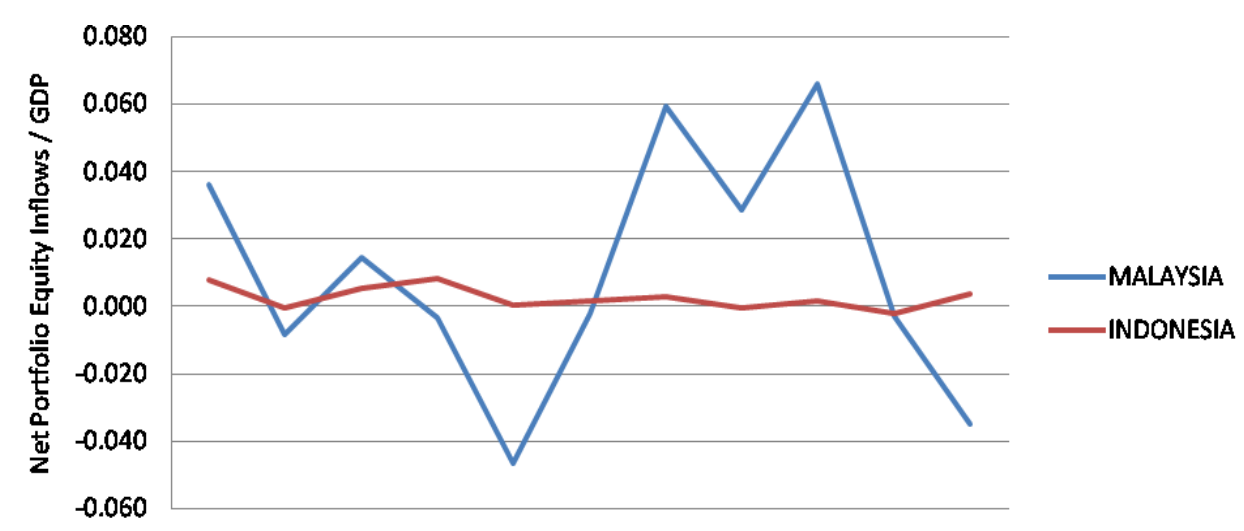

20042005200620072008200920102011201220132014

Figure 14. Net Portfolio Equity Inflows as a Proportion of GDP

Sources: Authors' own calculations using data from World Bank WDI, IMF IFS and Department of Statistics of various countries.

Figures 13 and 14 depict the capital mobility over time. From Figures 13 and 14, it can be seen that Malaysia recorded wider fluctuations in net FDI inflows as a proportion of GDP and net portfolio equity inflows as a proportion of GDP, respectively, compared to Indonesia.

\section{Conclusion}

This paper examines the historical pattern of macroeconomic uncertainty of two developing countries in the South East Asia, namely Malaysia and Indonesia. We find that while both countries were affected by similar external sources of macroeconomic uncertainty such as the financial or economic crises, the global economic slowdowns, volatile commodity prices, geopolitical risks and the SARS outbreak, these countries were also subject to domestic sources of macroeconomic uncertainty which were confined to the particular country. The analyses indicate that as compared to Malaysia, Indonesia was exposed to more uncertain macroeconomic conditions stemming from internal issues such as political instability, anomalous weather conditions and natural disasters.

We further compare the macroeconomic uncertainty encountered by both countries using three broad categories of indicators for macroeconomic volatility, namely volatility as a macroeconomic outcome, domestic sources of macroeconomic volatility and external sources of macroeconomic volatility. The analyses reveal that Indonesia experienced more fluctuations compared to Malaysia when macroeconomic uncertainty is measured by volatility as a macroeconomic outcome and domestic sources of macroeconomic volatility. Contrarily, Malaysia displayed greater fluctuations than Indonesia when macroeconomic uncertainty is measured by external sources of macroeconomic volatility.

In sum, the analyses conducted on these two countries demonstrate the volatile macroeconomic conditions faced by developing countries. The findings may benefit policy 
makers, firms and other institutions to assist them in formulating appropriate policies or strategies to deal with such adverse situations. This is important because macroeconomic uncertainty may have destabilizing effects on the aggregate income, social welfare and business operations of these economies.

\section{References}

Abdul Majid, M. S., \& Kassim, S. (2009). Impact of the 2007 U.S. financial crisis on the emerging equity markets. International Journal of Emerging Markets, 4(4), 341-357. doi: $10.1108 / 17468800910991241$

Amerasinghe, N., \& Modesto, J. (2011). Foreign direct investment in Asia: Lessons of experience. Asian Institute of Management Working Paper, 12-003.

Bank Indonesia. (2005). 2005 Economic report on Indonesia. Retrieved from http://www.bi.go.id/en/publikasi/laporan-tahunan/perekonomian/Pages/lpi2005.as px

Bank Indonesia. (2006). 2006 Economic report on Indonesia. Retrieved from http://www.bi.go.id/en/publikasi/laporan-tahunan/perekonomian/Pages/lpi2006.as px

Bank Indonesia. (2007). 2007 Economic report on Indonesia. Retrieved from http://www.bi.go.id/en/publikasi/laporan-tahunan/perekonomian/Pages/lpi2007.as px

Bank Indonesia. (2008). 2008 Economic report on Indonesia. Retrieved from http://www.bi.go.id/en/publikasi/laporan-tahunan/perekonomian/Pages/lpi_08.as px

Bank Indonesia. (2010). 2010 Economic report on Indonesia. Retrieved from http://www.bi.go.id/en/publikasi/laporan-tahunan/perekonomian/Pages/lpi_2010.a spx

Bank Indonesia. (2012). 2012 Economic report on Indonesia. Retrieved from http://www.bi.go.id/en/publikasi/laporantahunan/perekonomian/Pages/lpi_2012.as px

Bank Negara Malaysia. (1997). Annual report. Retrieved from http://www.bnm.gov.my/ index.php?ch=en_publication_catalogue\&pg=en_publication_bnmar\&eId=box2\&lang= en\&yr $=1997$

Bank Negara Malaysia. (1998). Annual report. Retrieved from http://www.bnm.gov.my/ index.php?ch=en_publication_catalogue\&pg=en_publication_bnmar\&eId=box $2 \&$ lang= en\&yr $=1998$

Bank Negara Malaysia. (1999). Annual report. Retrieved from http://www.bnm.gov.my/ index.php?ch=en_publication_catalogue\&pg=en_publication_bnmar\&eId=box2\&lang= en\&yr=1999

Bank Negara Malaysia. (2005). Annual report. Retrieved from http://www.bnm.gov.my/ index.php?ch=en_publication_catalogue\&pg=en_publication_bnmar\&eId=box $2 \&$ lang= en\&yr $=2005$

Bank Negara Malaysia. (2008). Annual report. Retrieved from http://www.bnm.gov.my/ 
index.php?ch=en_publication_catalogue\&pg=en_publication_bnmar\&eId=box $2 \&$ lang $=$ en\&yr $=2008$

Bank Negara Malaysia. (2009). Annual report. Retrieved from http://www.bnm.gov.my/ index.php?ch=en_publication_catalogue\&pg=en_publication_bnmar\&eId=box2\&lang= en\&yr $=2009$

Bayhaqi, A. (2006). Education and economic growth in Indonesia. (Unpublished Doctoral dissertation). National University of Singapore, Singapore.

Chandra, A. C. (2011). A dirty word? Neo-liberalism in Indonesia's foreign economic policies. Retrieved from http://www.iisd.org/tkn/pdf/dirty_word.pdf

Cucculelli, M., \& Bettinelli, C. (2016). Corporate governance in family firms, learning and reaction to recession. Evidence from Italy. Futures, 75, 92-103. http://dx.doi.org/10.1016/ j.futures.2015. 10.011

Gill, I., \& Kharas, H. (2007). An East Asian renaissance: Ideas for economic growth. Retrieved from http://siteresources.worldbank.org/INTEASTASIAPACIFIC/Resources/226262-1158536715202/EA_ Renaissance_full.pdf

Goldman Sachs Investment Strategy Group. (2013). Emerging markets: As the tide goes out. Retrieved from http://www.goldmansachs.com/what-we-do/investment-management/privatewealth-management/intellectual-capital/isg-insight-2013.pdf

Harvie, C. (1999). Indonesia: Recovery from economic and social collapse. University of Wollongong Working Paper, 99-5.

Inoue, T., Toyoshima, Y., \& Hamori, S. (2012). Inflation targeting in Korea, Indonesia, Thailand and the Philippines: The impact on business cycle synchronization between each country and the world. Institute of Developing Economies Discussion Paper, No. 328.

International Monetary Fund. (2015, January). World economic outlook. Retrieved from http:/www.imf.org/external/pubs/ft/weo/2015/update/01/pdf/0115.pdf

Katz, J., \& Bernat, G. (2010, November). Micro to macro interactions in the context of Argentine manufacturing activities: Exit and entry, productivity growth, structural change and innovative behavior in response to changes in the macroeconomic policy regime. Paper presented at the Globelics $20108^{\text {th }}$ International Conference on Making Innovation Work for Society: Linking, Leveraging and Learning, Kuala Lumpur, Malaysia. $\quad$ Retrieved from http://umconference.um.edu.my/upload/43-1/papers/066\%20JorgeKatz_Gonzalo Bernat.pdf

Kose, M. A., \& Prasad, E. S. (2010). Emerging markets: Resilience and growth amid global turmoil. Washington, DC: The Brooking Institution. 


\section{Macrothink}

Research in Applied Economics

ISSN 1948-5433

2017, Vol. 9, No. 4

Olaberria, E., \& Rigolini, J. (2009). Managing East Asia's macroeconomic volatility. The World Bank East Asia and Pacific Region Social Protection Unit Policy Research Working Paper, 4989.

Sinnakkannu, J., \& Nassir, A. M. (2008). Revisiting the causes of the East Asian financial crisis: Was it predictable? International Journal of Economic Perspectives, 2(2), 78-93.

Wagner, H. (2003). Globalization and financial instability: Challenges for exchange rate and monetary policy. Diskussionsbeiträge Fachbereich Wirtschaftswissenschaft, No. 347.

World Bank. (2009, April). East Asia and Pacific update. Retrieved from http://www.unicef.org/eapro/update_april09_fullreport.pdf

Zain, S. R. (2003). An empirical study of Malaysian firms' capital structure. (Unpublished Doctoral dissertation). University of Plymouth, U.K.

\section{Notes}

Note 1. Since 2004, KLSE has changed its name to Bursa Malaysia.

Note 2. Openness coefficient $=($ Exports + Imports $) /$ GDP

\section{Copyright Disclaimer}

Copyright for this article is retained by the author(s), with first publication rights granted to the journal.

This is an open-access article distributed under the terms and conditions of the Creative Commons Attribution license (http://creativecommons.org/licenses/by/3.0/). 